\title{
The Role of Saudi Universities in Serving and Developing Society for Vision 2030: Evidence from Jouf University
}

\author{
Emad Abdel KhaleK Saber El-Tahan ${ }^{1}$, Benlaria Houcine ${ }^{1}$, Ibrahim Ahmed ELamin Eltahir ${ }^{1} \&$ Sanaa Mostafa \\ Mohammed Mohammed ${ }^{1}$ \\ ${ }^{1}$ Department of Business Administration, Jouf University, Saudi Arabia \\ Correspondence: Benlaria Houcine, Department of Business Administration, Jouf University, Saudi Arabia.
}

Received: March 10, 2021

doi:10.5430/ijhe.v10n5p138
Accepted: May 5, 2021

Online Published: May 13, 2021

URL: https://doi.org/10.5430/ijhe.v10n5p138

\begin{abstract}
This research aimed to study the effects of The Role of Jouf University in serving and developing the society for Vision 2030, by understanding the influence of training, continuous education, technical consultations, and applied researches on management development for employees and organizational development of institutions. For this purpose, a questionnaire was distributed to a sample size of 393 individuals in the Kingdom of Saudi Arabia. Further, to analyze the study data, the structural equations method (SEM) was used via the SmartPLS and statistical package for the social science (SPSS) 23 programs. After analyzing and testing the hypotheses of the study, it was found that there is a positive role of Jouf University in serving and developing the society for Vision 2030. There is a positive impact for applied researches and training on management development of employees, and a positive impact also for applied researches, training, and continuing education on organizational development of institutions.
\end{abstract}

Keywords: Jouf University, training, continuous education, technical consultations, applied researches, management development for employees, organizational development of institutions, Vision 2030

\section{Introduction}

Today's world is witnessing fast-paced and comprehensive shifts in all domains of economic, social, knowledge, educational, and political aspects of life. Such transformations have their impact on the community through developing novel intellectual and scientific styles; this provides an opportunity that is to be utilized and acted upon. The university, with its broader concept and role, has to do with all this change and transformation which has touched all walks of life in the community. Those who observe the status quo of higher education globally, which is represented by universities, can discern that the roles of universities are also transforming on a large scale in terms of concept, practice, and application.

There is a growing global consensus that universities can play a role in economic growth and social development in a knowledge-based society; it is incumbent upon universities to shoulder a great responsibility towards their societies. For many years, universities have been like "ivory towers," which work in isolation from their community and surroundings. This description has been adopted since the nineteenth century-universities being places where thinkers live being immersed in education and research, yet they are isolated from the practical and applied aspects of daily life and society. Thus, a new concept of a university's role in acquiring knowledge has emerged. This new concept is knowledge-centered, as it constitutes a major element in developing and creating products that serve the community and the individuals.

Saudi universities have a crucial and instrumental role in achieving the kingdom's vision for 2030. Only universities can perform such a role, as they are required to carry out comprehensive sustainable development and engage in effective community participation through activating the third function of universities, which is to play their active role in the formation and development of the economy and the knowledge-based society through community service, developing community skills, and contributing to the enhancement of the local community to promote Vision 2030.

The mission of Jouf University is to offer educational and research outputs for the development of society. Thus, Jouf University has long been keen to pay due attention to the third axis of its mission-community service being administered through the Deanship of Community Service and Continuous Education, with the assistance of the university's colleges and other support deanships, counseling, and health centers and units. These bodies are devoted to provide and implement numerous training programs, along with offering public, educational, and awareness 
lectures in all domains of life for various individuals and groups of the society. Such efforts are aimed to bolster the relationship between the university and society, particularly via its activities and various community events.

In its essence, organizational development is a positive plan, i.e., enhancing the efficiency of the performance of the administrative apparatus in organizations, developing it, and shifting it from one stage to another stage, characterized by being more efficient, effective, and appropriate to respond to the changes taking place in the environment and the fast-paced life.

Now and then, organizations, whether public or private - governmental and non-governmental—are required to change and develop, to enhance their efficiency, performance, and productivity. This development, initially, aims to influence managers to change their mindsets associated with several areas of their activities, which have been formed as a result of traditional concepts that have affected them over time.

Therefore, Jouf University is always keen to provide community services to the largest segment of society, by offering a wide range of activities and programs to build close and constructive relationships and community partnerships with various sectors of society on an ongoing basis. Accordingly, the university's annual training plan aims to serve and develop the local community in line with the university's strategic plan, to implement quality programs that have a positive impact on individuals and different sectors of society.

In this context, Jouf University, represented by the Deanship of Community Service and Continuous Education, offered 299 programs (149 training courses, 130 lectures, 15 workshops, 4 training programs, and 1 seminar), whereas the total beneficiaries of those programs reached 27,038 people (males: 12910; females: 14128), representing the different groups of the local community as follows: 13,479 public sector employees, 2,945 private sector employees, 3,495 current university students, 6,371 unemployed, 268 individuals working in the freelance sector, 87 individuals working in the charitable sector, and 393 employees in the military sector. (Note 1)

Through an accurate review of what has been proposed in the future vision of the Kingdom of Saudi Arabia for 2030, its main focus on human capital is apparent; the Saudi leaders' aspirations are crystallized in shifting the kingdom from solely depending on oil as a basic source. This will only be possible if its mature minds are capable of finding new resources that can be used in the future.

It can be said that the future vision of the Kingdom of Saudi Arabia 2030 replaces oil with the human mind; therefore cultivating such minds within societies is closely dependent on educational institutions, i.e., universities.

In this respect, the kingdom has held many seminars and conferences that addressed the role of universities in (activating) Vision 2030, but the current research will address the role of universities in (realizing) Vision 2030. One of these models highlights "Jouf University." It should also be noted that activation differs from realization as the former refers to several recommendations that are presented to universities and those responsible for Vision 2030. Such recommendations can be either embraced or ignored as they do not go beyond the realm of operational procedures where they can be implemented or applied.

As for the current research, it aims to address the role of Jouf University in serving and developing the local community to achieve Vision 2030, by shedding light on its strategic objectives concerning community participation and how the university works to implement these strategic objectives through serving and developing the local community to achieve Vision 2030.

\section{Problem Statement}

Through the pilot study conducted by the researcher, the research problem can be stated in the form of the following main question:

To what extent does the role of Jouf University contribute to serving and developing the local community to achieve Vision 2030?

This main question can be broken into a set of sub-questions as follows:

1. What is the status quo of the contribution Jouf University makes in serving and developing the local community to achieve Vision 2030 ?

2. What is the degree of participation of faculty members at Jouf University in local community service and development programs to achieve Vision 2030?

3. What is the nature of the relationship between the role played by Jouf University in serving the community and developing the local community to achieve vision 2030 ? 
4. What is the extent of the impact of Jouf University in community service on the development of the local community to achieve Vision 2030?

\section{Literature Review}

\section{First: Literature Review Associated with Community Service}

Levkoe et al. (2020) pointed out that the Community Service-Learning (CSL) program has gained popularity over the past decades in universities across North America. Although planning programs tend to involve more graduate-level and community-engaged learning than other professional disciplines, learning outcomes have not been sufficiently examined. Based on a review of existing literature and analysis from four years of a CSL course at the University of Toronto's Department of Geography and Planning, this article describes the implications of CSL for graduate planning education. We argue that CSL in graduate planning programs has a series of unique characteristics and, thus, requires distinctive pedagogical approaches.

Wondwosen (2019) noted that the goals of higher education in Ethiopia are closely linked to national development and poverty reduction. Accordingly, higher education institutions are expected to align them with major activities based on national needs and community service. The Ethiopian Higher Education Proclamation (2009) identifies "the design and provision of community and consultancy services that shall cater to the developmental needs of the country" as one of the objectives and a major educational institution. The Ethiopian Education Sector Development Program V (2015) also emphasizes the need for positive community engagement through various means, including research that can respond to national and institutional priorities and developmental plans. It also emphasizes the need for community consultation and envisages the establishment of a multi-sectoral stakeholder panel, to produce a national research and community engagement framework, institutional research, and community engagement strategies for community participation.

Through their study on community service in Saudi Arabian universities, a comparative study by Alfares et al. (2013) presented an analysis of community service activities offered by higher education institutions in Saudi Arabia. The descriptive approach along with literature survey, benchmarking, questionnaires, and focus group meetings were employed, and community service definitions and activities were surveyed in several countries. A benchmarking comparison was made between community service programs in 10 major Saudi universities and 20 top American universities. The comparisons showed that Saudi universities lag behind top U.S. and international universities in terms of community service. The study provided a set of improvements concerning community service.

Clinton and Thomas (2011) aimed to explore business students' experience of service-learning in the community; this is a name given to integrating community service in students' courses. Community educational service can be thought of as a subset of work-integrated learning. Most universities now include community service, which is helping the community while also enabling the students to gain the professional skills they may require in the future. The industry requires that university graduates be equipped with technical knowledge as well as with graduate abilities/attributes and/or general skills, such as communication skills, teamwork, and problem-solving abilities. This study was based on business students' experience to serve the educational community via their efforts.

\section{Second: Literature Review Related to Management and Organizational Development}

Chang et al. (2011) tackled the dynamics of intellectual capital in organizational development, in Taiwan, by addressing and analyzing the relationship between intellectual capital (IC) and organizational development, to catch up with the ongoing environmental changes. The results indicate that firms place relatively different weights on the development of IC components across life cycle stages, and such investments have different consequences in terms of the financial performance of firms in Taiwan.

Grassl (2010) presented Aquinas' psychological theory of action as a useful guide for understanding decision-making in management. Aquinas' theory of action allows for a prescription that harmonizes instrumental rationality, the will, and personal morality for building management development. Aquinas also borrowed from Aristotle a stark distinction between theoretical actual (contemplative) ability and applied (arithmetic) ability in the United States of America. Additionally, he composed a model stating that the actual theoretical ability is concerned with all the laws of the world and behavior to study the fixed facts that do not change. As for the actual scientific ability, it is employed to look for what is temporal and therefore contributes to developing knowledge of how we imperatively act towards certain objectives.

The study conducted by Sherif and Ragaa (2008) explored the ways develop the local administration system utilizing, the business process re-engineering (BPR) and the extent to which this approach can be applied to the current local administration system and the local administration system at the governorate level in the Arab Republic of Egypt, 
along with adopting a planning system based on a blend of strategic and regional planning systems and the development of local administration systems.

This study made the following conclusions:

- It is necessary to shift towards decentralization and re-engineering the organizational structure.

- It is necessary to re-engineer the human resource system for local administration and developing the management system.

- A link between re-engineering administrative training for local administration and the development of the local administration system exists (Sherif \& Ragaa, 2008)

Gibson (2008) highlighted the proper concept of management development since the actual practices of management contradict this concept. Management principles include not considering management as a human activity or a chain of events. This study concluded that the management development activity refers to the external and incidental aspects of the action where the psychological aspect cannot be ignored.

Azad and Faraj (2008) tend to initiate management and organizational reform, making improvements in IT and communication services provided to citizens, businesses, and the Land Registry of Lebanon. The results yielded in developing a model of several steps, based on consultation and taking the opinions of citizens and stakeholders, in terms of making an evaluation of the current system, reformulating and evaluating the proposed model, and adopting the mandatory model - the work stability model.

Al-Sabeel (2008) sought to define the role of management development in the success of e-government as she focused on the organizational requirements that have an impact. The study also tackled the concept of the state and administrative theories, particularly bureaucratic; it provided an illustration of the significance of organizational structure and the impact of management development on its continuity and modernization, and the extent of the impact of the key factors on an administrative organization in terms of utilizing high technology, laws, and regulations, and how much they are clear and flexible. This is coupled with studying the impact attained by using technology in municipal and rural affairs in the Kingdom of Saudi Arabia. The conclusions made by the study include:

- Restructuring the organization in a manner that fulfills the requirements of change in conformity with the application of e-government

- Reviewing the job structure and re-planning the workforce in conformity with the organizational structure

- The top management should adopt the principle of implementing e-government and supporting the attitudes towards it

- Reviewing the regulations, reformulating them, and preparing them to be more comprehensive and flexible to implement e-government

- Drawing out and setting the necessary plans for training and qualifying the workforce

A study by Otenyo and Lind (2006) discussed the issue of management development and development management (development). They also compared and contrasted the concepts of management development and development management in large government institutions in Norway. This study concluded that there is a strong relationship between both concepts. According to them, management development primarily relies on actions that aim to create new institutions, especially government departments. Moreover, the term "development management" is employed in most parts of the world, to refer to reconstruction engineering.

Jabri and Pounder (2001) tried to examine change management from the perspective of management development; it explores the role of narrative in management development. The study draws attention to the value of the narrative, in enriching knowledge of the effects of change on individuals. It is argued that narratives express the richness and diversity of human experience and, thus, challenge simplistic analyses of management issues such as the change that can result from adherence to narrow mechanical models of human nature. Hence, the narrative is recommended as a valuable tool for conveying the reality of managerial situations to practitioners engaged in management development.

van der Sluis-den Dikken and Hoeksema (2001) aimed to explain that management development is a cornerstone. The study also showed that the central challenge of management development is to control and manage the learning process of managers, focused on individual development and career success and/or reaching organizational goals. It concludes that the job, the work environment, and the individual employee characteristics play a role in creating management development. 
Reitsma (2001) described management development in Unilever as a strategic tool to assist the organization, to achieve its short-term and long-term objectives for management development process within the company. This study concluded that Unilever has undergone a rapid change. Additionally, management development has played an effective role in communicating this change throughout the organization as well as preparing employees to handle it.

Cochran (2000) sought to tackle the management policies adopted by the management units in developing countries as well as the issues they encounter and the means to solve them. The study also tried to illustrate the relationship between developing and developed countries in terms of the management practices embraced in each of them as well as in the local administrations in their respective countries. This study concluded the following:

- There is a need to resolve issues faced by the local government in developing countries

- Decentralization that empowers local units to encounter these problems must be supported

- No differences do exist between the management policies applied in both developing and developed countries

Based on the literature review about the role of universities in community service, the current study can extract the following dimensions: applied researches, continuous education, technical consultations, and training.

Based on the literature review associated with the development of organizations, the current study can extract the following dimensions: management development of employees and organizational development.

\section{Hypotheses}

The variables in the study are shown in Figure 1. The independent variable represents the role of Jouf University in serving the community in the following dimensions: training, continuous education, technical consultations, and applied researches, whereas the dependent variable is represented in the development of the local community to achieve the 2030 vision concerning the following dimensions: management development for employees and organizational development of institutions.

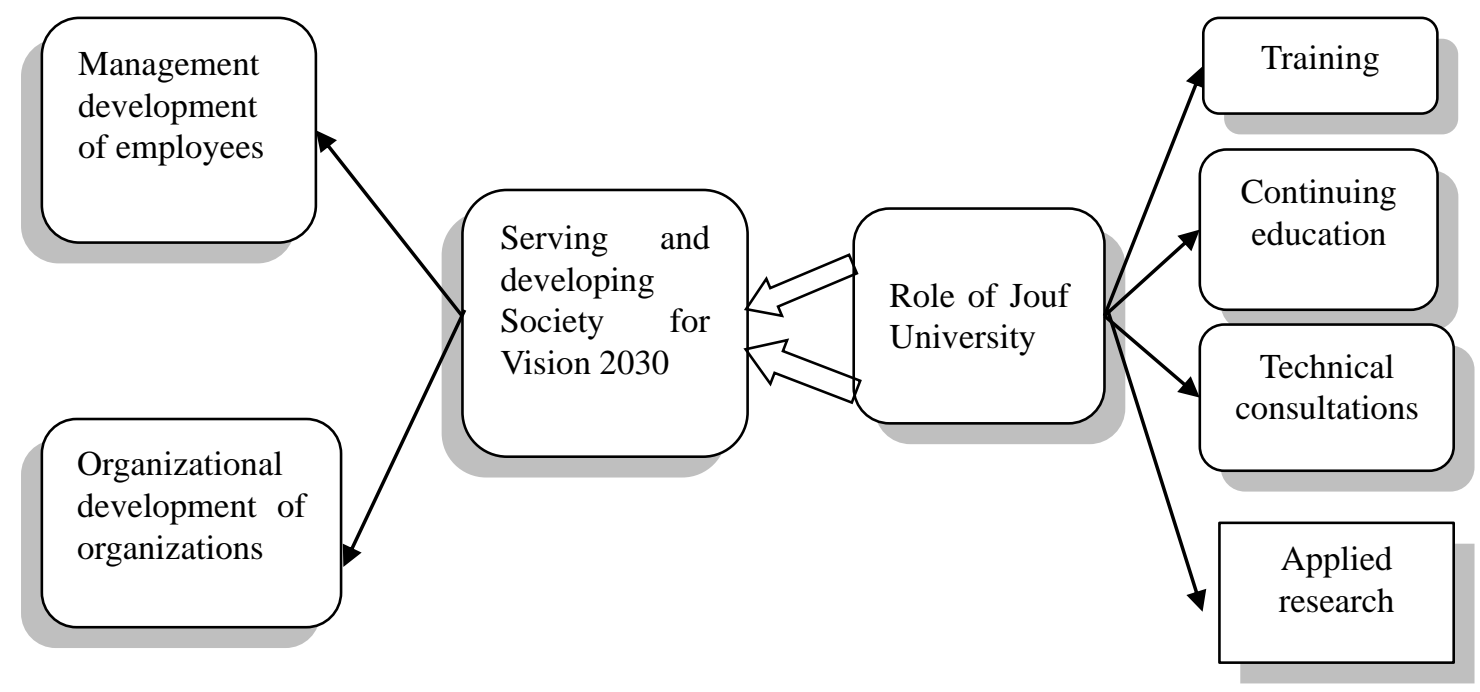

Figure 1. Research Variables and Dimensions

HP1. There is a statistically significant impact of applied researches on the management development of employees at a level of less than 0.05 .

HP2. There is a statistically significant impact of applied researches on organizational development at a level of less than 0.05 .

HP3. There is a statistically significant impact of continuing education on the management development of employees at a level of less than 0.05 .

HP4. There is a statistically significant impact of continuing education on organizational development at a level of less than 0.05 .

HP5. There is a statistically significant impact of technical consultations on the management development of employees at a level of less than 0.05 . 
HP6. There is a statistically significant impact of technical consultations on organizational development at a level of less than 0.05 .

HP7. There is a statistically significant impact of training on the management development of employees at a level of less than 0.05 .

HP8. There is a statistically significant impact of training on organizational development at a level of less than 0.05 .

HP9. Statistically, significant differences exist in the sample's views concerning the role of Jouf University due to demographic variables (gender, age, education, experience, and profession) at a level less than 0.05 .

HP10. Statistically, significant differences exist in the sample's views concerning the management development of employees due to demographic variables (gender, age, education, experience, and profession) at a level less than 0.05 .

HP11. Statistically, significant differences exist in the sample's views concerning organizational development due to demographic variables (gender, age, education, experience, and profession) at a level less than 0.05.

\section{Methodology}

The research population is composed of the beneficiaries of the community services rendered by Jouf University to the local community in the Kingdom of Saudi Arabia. A random sample was taken of the beneficiaries of Jouf University's programs, in serving and developing the local community, for the following reasons:

- The similarity of the characteristics of the research population in general

- Enabling the researchers to obtain a large portion of the responses from those surveyed

The study sample consists of 393 individuals over the age of 18 years. The research sample was determined based on an objective sampling method, which relied on the testing of individuals who had the information needed by the researcher.

An initial questionnaire was prepared for use in the collection of data and information. The questionnaire was then submitted to the arbitrators to test its suitability for all data. It was modified at the discretion of the arbitrators.

The questionnaire was divided into three parts:

- The first section consisted of the demographic data of the sample

- The second section dealt with variables that express the role of the Jouf University and was divided into the following axes: applied researches, continuous education, technical consultations, and training

- The third section concerned the dependent variable that expresses serving and developing Society for Vision 2030 and consisted of management development of employees and organizational development

The answers were based on the five-point Likert scale. Both the SmartPLS program and the SPSS program were used to analyze the data and test the hypotheses of the study.

\section{Results}

\subsection{Characteristics of the Sample}

The results related to the characteristics of the study sample that participated in the questionnaire in terms of gender, age, education, experience, and profession are shown in the tables below. 
Table 1. Distribution of the sample by gender, age, and education

\begin{tabular}{llccc}
\hline Variable & Items & Frequency & Percentage (\%) & Cumulative Percentage (\%) \\
\hline Gender & Male & 220 & 57.4 & 57.4 \\
& Female & 163 & 42.6 & 100 \\
Age & $15-20$ & 48 & 12.5 & 12.5 \\
& $21-30$ & 123 & 32.1 & 44.6 \\
& $30-40$ & 94 & 24.5 & 69.2 \\
& $40-50$ & 95 & 24.8 & 94 \\
& More than 50 years & 23 & 6 & 100 \\
Education & less than high school & 113 & 29.5 & 53.3 \\
& High school & 91 & 23.8 & 99.5 \\
& Bachelor & 177 & 46.2 & 100
\end{tabular}

Table 1 shows that $57.4 \%$ of the sample is male and $42.6 \%$ female. The largest percentage of the sample studied $(32.1 \%)$ is between 21 and 30 years of age. It is followed by the age group of 40-50 years (24.8\%) and then by the age group of $30-40$ years $(24.5 \%)$. Table 1 also shows that $46.2 \%$ of the sample has a bachelor's degree, $5 \%$ has a master's degree or higher, $23.8 \%$ has a high school education level, and $29.5 \%$ has an education level lower than high school.

Table 2. Distribution of the sample by experience and profession

\begin{tabular}{lcccc}
\hline Variable & Items & Frequency & Percentage (\%) & Cumulative Percentage (\%) \\
\hline Experience & No experience & 113 & 35.8 & 35.8 \\
& Fewer than a year & 15 & 3.9 & 39.7 \\
$1-3$ & 24 & 6.3 & 46 \\
$3-6$ & 177 & 46.2 & 92.2 \\
& $6-9$ & 5 & 1.3 & 93.5 \\
profession & Greater than 9 & 25 & 6.5 & 100 \\
& Don't work & 15 & 3.9 & 3.9 \\
& Government employee & 184 & 48 & 52 \\
& Private sector employee & 154 & 40.2 & 92 \\
& Freelance business & 30 & 7.8 & 100
\end{tabular}

Table 2 shows that $48 \%$ of the study sample is employed in the government sector, $40.2 \%$ is employed in the private sector, $3.9 \%$ is unemployed, and 7.8\% in freelance business. $46.2 \%$ of the sample has experience between 3-6 years, $35.8 \%$ has no experience, and the least experience percentage is $1.3 \%$, which is between $6-9$ years.

\subsection{Assessment of Measurements Model}

\section{A. Convergent validity:}

To analyze the study data and test the validity of the hypotheses, we will use one of the most effective statistical tools-PLS-SEM modeling of structural equations (Tenenhaus \& Amato, 2004). 
The process of checking the quality and conformity of the measurement model is the first essential step; the calculation of the following indicators was used: Cronbach's alpha, the composite reliability, and the average variance extracted (AVE).

Table 3. Results of measurements model—convergent validity

\begin{tabular}{|c|c|c|c|c|c|c|}
\hline Items & Constructs & loading & Cronbach's Alpha & rho_A & $\begin{array}{l}\text { Composite } \\
\text { Reliability }\end{array}$ & $\begin{array}{l}\text { Average Variance } \\
\text { Extracted (AVE) }\end{array}$ \\
\hline AR1 & \multirow{3}{*}{ 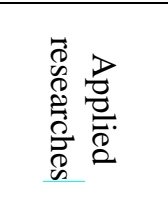 } & 0.701 & \multirow{3}{*}{0.744} & \multirow{3}{*}{0.780} & \multirow{3}{*}{0.853} & \multirow{3}{*}{0.662} \\
\hline AR2 & & 0.888 & & & & \\
\hline AR3 & & 0.848 & & & & \\
\hline CE1 & \multirow{3}{*}{ 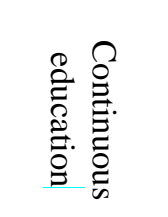 } & 0.865 & \multirow{3}{*}{0.819} & \multirow{3}{*}{0.837} & \multirow{3}{*}{0.891} & \multirow{3}{*}{0.732} \\
\hline CE2 & & 0.871 & & & & \\
\hline CE3 & & 0.829 & & & & \\
\hline MD1 & \multirow{4}{*}{ 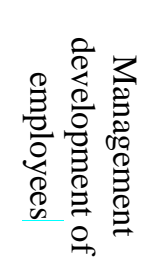 } & 0.745 & \multirow{4}{*}{0.765} & \multirow{4}{*}{0.768} & \multirow{4}{*}{0.850} & \multirow{4}{*}{0.587} \\
\hline MD2 & & 0.780 & & & & \\
\hline MD3 & & 0.776 & & & & \\
\hline MD4 & & 0.763 & & & & \\
\hline OD1 & \multirow{5}{*}{ 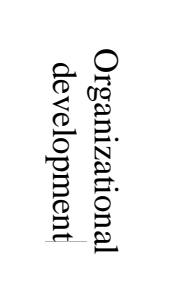 } & 0.740 & \multirow{5}{*}{0.879} & \multirow{5}{*}{0.883} & \multirow{5}{*}{0.912} & \multirow{5}{*}{0.676} \\
\hline OD2 & & 0.823 & & & & \\
\hline OD3 & & 0.812 & & & & \\
\hline OD5 & & 0.835 & & & & \\
\hline OD6 & & 0.893 & & & & \\
\hline TC1 & \multirow{3}{*}{ 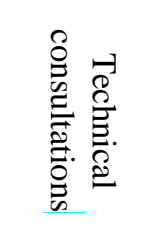 } & 0.902 & \multirow{3}{*}{0.875} & \multirow{3}{*}{0.876} & \multirow{3}{*}{0.923} & \multirow{3}{*}{0.800} \\
\hline TC2 & & 0.884 & & & & \\
\hline TC3 & & 0.898 & & & & \\
\hline TR1 & \multirow{4}{*}{ ت. } & 0.815 & \multirow{4}{*}{0.820} & \multirow{4}{*}{0.824} & \multirow{4}{*}{0.882} & \multirow{4}{*}{0.652} \\
\hline TR2 & & 0.770 & & & & \\
\hline TR3 & & 0.875 & & & & \\
\hline TR4 & & 0.765 & & & & \\
\hline
\end{tabular}

Source: Prepared by researchers using SmartPLS outputs.

The composite reliability, Cronbach's alpha, and internal quality reliability value should all be above 0.70 . (Hair et al., 2017). In the measurement assessment, the analysis considers composite reliability, AVE (AVE=convergent validity), outer loading, Cronbach's 5-007, and discriminatory validity. Table 3 showed that the average variance of the extracted AVE values was above the minimum required level of 0.50 , reflecting the fact that the questionnaire reflects the characteristics of the model and each study variable (Hair et al., 2010).

\section{B. Discriminant validity test:}

The first step in which the one-dimensional evaluation of the latent variables was carried out and the measured variables were filtered to measure those variables well and honestly. 
After assessing the validity of the variables of the measurement model and making the necessary adjustments, a second step was carried out: the assessment of the validity of the differentiation of the path model in which the Fornell-Larcker criterion was analyzed, as shown in Table 4:

Table 4. Results of latent variable correlations

\begin{tabular}{|c|c|c|c|c|c|c|}
\hline & $\begin{array}{l}\text { Applied } \\
\text { researches }\end{array}$ & $\begin{array}{l}\text { Continuous } \\
\text { education }\end{array}$ & $\begin{array}{l}\text { Management } \\
\text { development } \\
\text { of employees }\end{array}$ & $\begin{array}{l}\text { Organizational } \\
\text { development }\end{array}$ & $\begin{array}{l}\text { Technical } \\
\text { consultations }\end{array}$ & Training \\
\hline $\begin{array}{l}\text { Applied } \\
\text { researches }\end{array}$ & $\underline{0.813}$ & & & & & \\
\hline $\begin{array}{l}\text { Continuous } \\
\text { education }\end{array}$ & 0.706 & $\underline{0.855}$ & & & & \\
\hline $\begin{array}{l}\text { Management } \\
\text { development of } \\
\text { employees }\end{array}$ & 0.745 & 0.658 & $\underline{0.766}$ & & & \\
\hline $\begin{array}{l}\text { Organizational } \\
\text { development }\end{array}$ & 0.655 & 0.627 & 0.719 & $\underline{0.822}$ & & \\
\hline $\begin{array}{l}\text { Technical } \\
\text { consultations }\end{array}$ & 0.777 & 0.709 & 0.682 & 0.587 & $\underline{0.894}$ & \\
\hline Training & 0.608 & 0.771 & 0.631 & 0.600 & 0.645 & $\underline{0.807}$ \\
\hline
\end{tabular}

Source: Prepared by researchers using Smart PLS outputs.

Fornell-Larcker criterion is widely used to measure the degree of mutual variance between latent variables of the model (Fornell \& Larcker, 1981). Quadratic root comparison is rendered using latent variable correlations with AVE values (Hair et al., 2017). The estimated values are less than 0.9, which implies that the discriminant validity has been recognized. The findings have shown that the measurement scales are reliable and valid.

Therefore, it can be said that the model is more valid for differentiation than other possible constructions. Additionally, cross-load coefficients are analyzed with external load factors for each latent variable in the following table:

Table 5. Results of discriminant validity—cross loadings

\begin{tabular}{|c|c|c|c|c|c|c|c|}
\hline Items & Constructs & $\begin{array}{l}\text { Applied } \\
\text { researches }\end{array}$ & $\begin{array}{l}\text { Continuous } \\
\text { education }\end{array}$ & $\begin{array}{l}\text { Management } \\
\text { development } \\
\text { of employees }\end{array}$ & $\begin{array}{c}\text { Organizational } \\
\text { development }\end{array}$ & $\begin{array}{l}\text { Technical } \\
\text { consultations }\end{array}$ & Training \\
\hline AR1 & \multirow{3}{*}{$\begin{array}{l}\text { Applied } \\
\text { researches }\end{array}$} & $\begin{array}{l}(0.867) \\
\end{array}$ & 0.519 & 0.493 & 0.390 & 0.656 & 0.461 \\
\hline AR2 & & $\underline{(0.888)}$ & 0.617 & 0.651 & 0.509 & 0.706 & 0.495 \\
\hline AR3 & & $\underline{(0.848)}$ & 0.587 & 0.756 & 0.658 & 0.570 & 0.528 \\
\hline CE1 & \multirow{3}{*}{$\begin{array}{l}\text { Continuous } \\
\text { education }\end{array}$} & 0.573 & $\underline{(0.865)}$ & 0.519 & 0.543 & 0.540 & 0.699 \\
\hline CE2 & & 0.667 & $\underline{(0.871)}$ & 0.638 & 0.636 & 0.645 & 0.637 \\
\hline CE3 & & 0.558 & $\underline{(0.829)}$ & 0.513 & 0.394 & 0.635 & 0.649 \\
\hline MD1 & \multirow{4}{*}{$\begin{array}{l}\text { Management } \\
\text { development } \\
\text { of employees }\end{array}$} & 0.679 & 0.409 & $\underline{(0.745)}$ & 0.458 & 0.560 & 0.317 \\
\hline MD2 & & 0.679 & 0.494 & $(0.780)$ & 0.400 & 0.612 & 0.506 \\
\hline MD3 & & 0.560 & 0.616 & $\underline{(0.776)}$ & 0.679 & 0.464 & 0.581 \\
\hline MD4 & & 0.511 & 0.488 & $\underline{(0.763)}$ & 0.679 & 0.445 & 0.519 \\
\hline OD1 & \multirow{4}{*}{$\begin{array}{c}\text { Organizational } \\
\text { development }\end{array}$} & 0.579 & 0.507 & 0.630 & $\underline{(0.740)}$ & 0.531 & 0.409 \\
\hline OD2 & & 0.581 & 0.558 & 0.592 & $\underline{(0.823)}$ & 0.465 & 0.484 \\
\hline OD3 & & 0.456 & 0.432 & 0.556 & $\underline{(0.812)}$ & 0.391 & 0.484 \\
\hline OD5 & & 0.474 & 0.517 & 0.575 & $(0.835)$ & 0.431 & 0.586 \\
\hline
\end{tabular}




\begin{tabular}{cccccccc} 
OD6 & & 0.586 & 0.547 & 0.595 & $\underline{(\mathbf{0 . 8 9 3})}$ & 0.575 & 0.503 \\
TC1 & Technical & 0.702 & 0.696 & 0.613 & 0.562 & $\underline{(\mathbf{0 . 9 0 2})}$ & 0.634 \\
TC2 & consultations & 0.705 & 0.609 & 0.582 & 0.499 & $\underline{(\mathbf{0 . 8 8 4})}$ & 0.511 \\
TC3 & & 0.680 & 0.597 & 0.633 & 0.512 & $\underline{(\mathbf{0 . 8 9 8})}$ & 0.580 \\
TR1 & Training & 0.509 & 0.659 & 0.473 & 0.425 & 0.619 & $\underline{\underline{(\mathbf{0 . 8 1 5})}}$ \\
TR2 & & 0.455 & 0.501 & 0.494 & 0.514 & 0.425 & $\underline{(\mathbf{0 . 7 7 0})}$ \\
TR3 & & 0.449 & 0.616 & 0.526 & 0.550 & 0.476 & $\underline{(\mathbf{0 . 8 7 5})}$ \\
\hline
\end{tabular}

Source: Prepared by researchers using Smart PLS outputs

Through Table 5, all the items of the study have a high level of saturation on the underlying variables, and the linkage of the items with the latent variables exceeded the minimum value of 0.7 ; some items were excluded due to the low level of their saturation on the underlying variables.

Table 6. HTMT Results

\begin{tabular}{|c|c|c|c|c|c|c|}
\hline & $\begin{array}{l}\text { Applied } \\
\text { researches }\end{array}$ & $\begin{array}{l}\text { Continuous } \\
\text { education }\end{array}$ & $\begin{array}{l}\text { Management } \\
\text { development } \\
\text { of employees }\end{array}$ & $\begin{array}{l}\text { Organizational } \\
\text { development }\end{array}$ & $\begin{array}{l}\text { Technical } \\
\text { consultations }\end{array}$ & Training \\
\hline $\begin{array}{l}\text { Applied } \\
\text { researches }\end{array}$ & & & & & & \\
\hline $\begin{array}{l}\text { Continuous } \\
\text { education }\end{array}$ & 0.898 & & & & & \\
\hline $\begin{array}{l}\text { Management } \\
\text { development } \\
\text { of employees }\end{array}$ & 0.878 & 0.817 & & & & \\
\hline $\begin{array}{l}\text { Organizational } \\
\text { development }\end{array}$ & 0.785 & 0.719 & 0.882 & & & \\
\hline $\begin{array}{l}\text { Technical } \\
\text { consultations }\end{array}$ & 0.884 & 0.836 & 0.829 & 0.882 & & \\
\hline Training & 0.781 & 0.836 & 0.791 & 0.705 & 0.765 & \\
\hline
\end{tabular}

If the HTMT criterion is less than 0.90, it means that the two reflective structures are just identical and are not very much related (Henseler et al., 2014). Table 6 shows the value less than 0.90 shows the scales are reliable and valid.

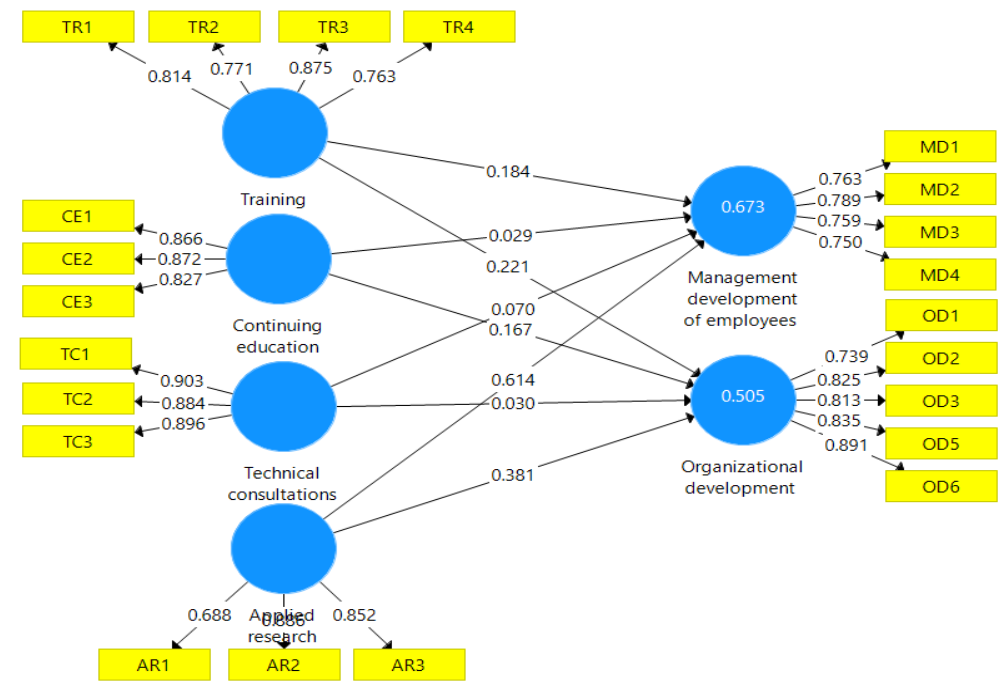

Figure 2. Research framework 
Figure 2 shows that the cross-loading coefficients for each latent variable, with the same variable, are higher than the cross-loading coefficients for the rest of the other latent variables, which in total surpassed the value of 0.7 . This is an indicator of the consistency of the measurement model structure.

\subsection{Assessment of Structural Model}

To test the quality of the structural model, we will use R-square, which demonstrates the predictive power of the model in the study sample and also describes the interpretation of the external latent constructs for the variance in the dependent variable.

Chin (1998) proposed that the value of R2 above 0.67 was considered strong, the values between 0.33 and 0.67 were moderate, the values between 0.19 and 0.33 were poor, and any R2 values below 0.19 were undesirable. Fallk and Miller (1992) suggest an R2 value of 0.10 as a minimum acceptable standard.

Additionally, f-square is used to denote the influence of each independent variable on the dependent variable. According to Cohen (1988), for $\mathrm{f} 2$ above 0.35, the magnitude of the effect is considered to be high.

This is the same for the Q2 scale, which tests the predictive power of the study model outside the test sample. According to Croutsche (2002), it has to be more than nil. (Fernandes, 2012, pp. 102-103). The values for all previous steps are shown in Table 7.

Table 7. R-square, f-square and $\mathrm{Q}^{2}$ of the latent variable

\begin{tabular}{lccc}
\hline \multicolumn{1}{c}{ Constructs } & R Square & f Square & $\mathrm{Q}^{2}$ \\
\hline Management development of employees & 0.673 & 0.669 & 0.385 \\
Organizational development & 0.505 & 0.500 & 0.334 \\
\hline
\end{tabular}

Source: Prepared by researchers using Smart PLS outputs.

Table 7 indicates that the estimated equation has an R2 value of 0.673 . It shows that $67.3 \%$ of the management development is represented by applied researches, continuous education, technical consultations, and training. 50.5\% of organizational development is described by applied researches, continuous education, technical consultations, and training.

As for the values of Q2, values greater than zero have been defined for all endogenous latent variables, indicating the prediction of dependent latent variables outside the research sample.

Table 8. Results of GOODNESS-OF-FIT

\begin{tabular}{lrr}
\hline & Saturated Model & Estimated Model \\
\hline SRMR & 0.092 & 0.096 \\
d_ULS & 2.155 & 2.322 \\
d_G & 1.146 & 1.170 \\
Chi-Square & 2262.514 & 2294.240 \\
NFI & 0.660 & 0.656
\end{tabular}

The data in Table 8 shows an acceptable measure of model fit, using a standardized root mean square residual (SRMR) (Dijkstra \& Henseler, 2015). Other models fit parameters using the PLS algorithm bootstrap for the determination of unweighted least square discrepancy (dULS) and geodesic discrepancy (dG) (Hair et al., 2017). Less than 0.1 SRMR is a conservative view; the estimated result of 0.092 is a reasonable match for SRMR. dG and dULS $<95$ percent of the quantile bootstrap is considered as a traditional view; the computed results of 1.146 and 2.155 represent the requirements met. Thus, the model achieves a good fit.

The proposed model has a high quality by the GOODNESS-OF-FIT metrics shown in Table 8 . And the GOODNESS-OF-FIT indicator also registered a value of 0.4673 , which is greater than 0.36 and is the minimum. (Wetzels et al., 2009).

\subsection{Testing Study Hypotheses}

Hypotheses HP1, HP2, HP3, HP4, HP5, HP6, HP7, and HP8 have been tested using the SmartPLS program as follows: 


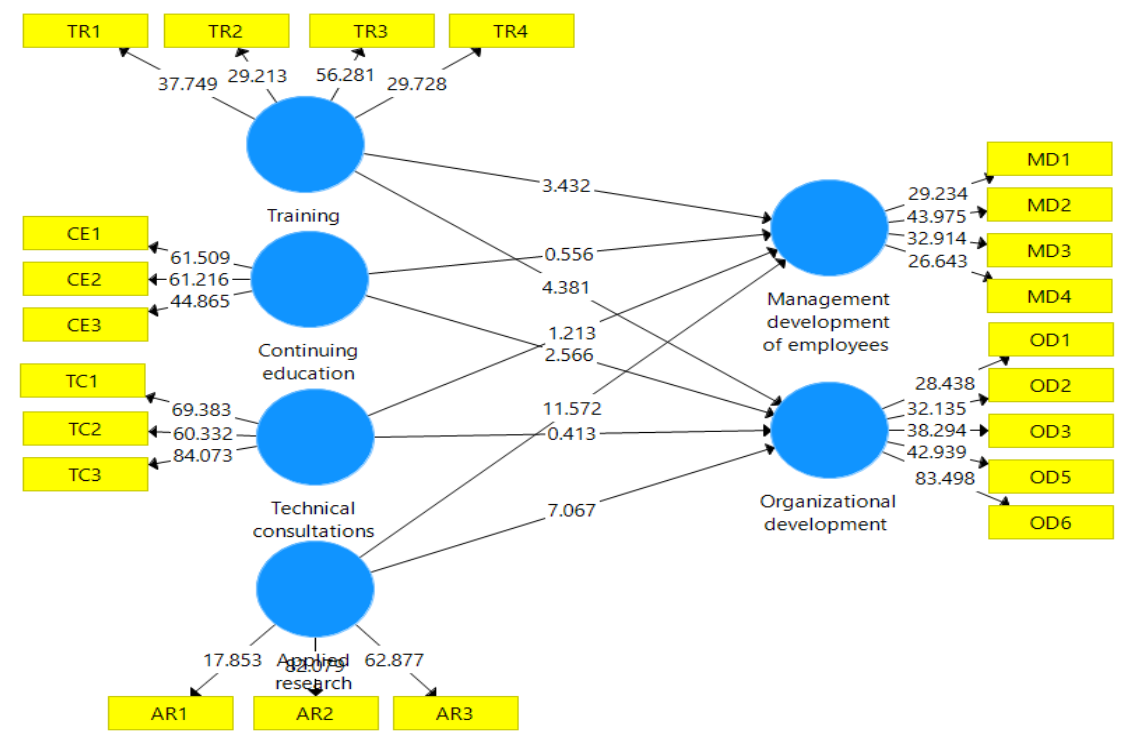

Figure 3. Path analysis on the impact of Jouf University on the development of the local community

Table 9. Path coefficient of the research hypotheses

\begin{tabular}{|c|c|c|c|c|c|c|}
\hline Нypo & Relationship & Std.Beta & Std. Error & T Values & P Values & Decision \\
\hline HP1 & $\begin{array}{l}\text { Applied researches -> } \\
\text { Management development } \\
\text { of employees }\end{array}$ & 0.614 & 0.054 & 11.329 & 0.000 & $\underline{\text { Supported } * *}$ \\
\hline HP2 & $\begin{array}{l}\text { Applied researches -> } \\
\text { Organizational } \\
\text { development }\end{array}$ & 0.381 & 0.052 & 7.377 & 0.000 & Supported $* *$ \\
\hline HP3 & $\begin{array}{l}\text { Continuing education -> } \\
\text { Management development } \\
\text { of employees }\end{array}$ & 0.029 & 0.058 & 0.494 & 0.621 & Unsupported \\
\hline HP4 & $\begin{array}{l}\text { Continuing education -> } \\
\text { Organizational } \\
\text { development }\end{array}$ & 0.167 & 0.065 & 2.586 & 0.010 & Supported** \\
\hline HP5 & $\begin{array}{l}\text { Technical consultations -> } \\
\text { Management development } \\
\text { of employees }\end{array}$ & 0.070 & 0.060 & 1.167 & 0.244 & Unsupported \\
\hline HP6 & $\begin{array}{l}\text { Technical consultations -> } \\
\text { Organizational } \\
\text { development }\end{array}$ & 0.030 & 0.066 & 0.452 & 0.651 & Unsupported \\
\hline HP7 & $\begin{array}{l}\text { Training -> Management } \\
\text { development of employees }\end{array}$ & 0.184 & 0.054 & 3.436 & 0.001 & Supported** \\
\hline HP8 & $\begin{array}{l}\text { Training -> Organizational } \\
\text { development }\end{array}$ & 0.221 & 0.054 & 4.127 & 0.000 & Supported** \\
\hline
\end{tabular}

Significant at $\mathrm{P}^{* *}=<0.01, \mathrm{p}^{*<0.05}$

It is clear to us from Table 9 and figures 5 that:

The first hypothesis was confirmed by the following: (Influence coefficient $=0.614, \mathrm{~T}$ Values $=11.329, \mathrm{P}$ Values $=$ 0.000). It can therefore be said that there is a positive, direct, and statistically significant effect of the applied researches on the management development of employees. 
The second hypothesis was confirmed by the following: (Influence coefficient $=0.381$, $\mathrm{T}$ Values $=7.377$, $\mathrm{P}$ Values $=$ 0.000). It can therefore be said that there is a positive, direct, and statistically significant impact of the applied researches on organizational development.

The third hypothesis was unconfirmed by the following: (Influence coefficient $=0.029$, $\mathrm{T}$ Values $=0.494$, P Values $=$ 0.621). From this, it can be said that there is no effect of continuing education on the management development of employees.

The fourth hypothesis was confirmed by the following: (Influence coefficient $=0.167, \mathrm{~T}$ Values $=2.586$, $\mathrm{P}$ Values $=$ 0.010). It can therefore be said that there is a positive, direct, and statistically significant impact of continuing education on organizational development.

The fifth hypothesis was unconfirmed by the following: (Influence coefficient $=0.070$, $\mathrm{T}$ Values $=1.167$, $\mathrm{P}$ Values $=$ 0.244). From this, it can be said that there is no effect of technical consultations on the management development of employees.

The sixth hypothesis was unconfirmed by the following: (Influence coefficient $=0.030$, $\mathrm{T}$ Values $=0.452$, P Values $=$ 0.651). From this, it can be said that there is no effect of technical consultations on organizational development.

The seventh hypothesis was confirmed by the following: (Influence coefficient $=0.184$, $\mathrm{T}$ Values $=3.436$, $\mathrm{P}$ Values $=$ 0.001). It can therefore be said that there is a positive, direct, and statistically significant effect of the training on the management development of employees.

The eighth hypothesis was confirmed by the following: (Influence coefficient $=0.221$, $\mathrm{T}$ Values $=4.127$, P Values $=$ 0.000). It can therefore be said that there is a positive, direct, and statistically significant effect of the training on organizational development.

The bootstrap results in table 10 can be indicated to confirm the previous results:

Table 10. Results of confidence intervals: bootstrap

\begin{tabular}{|c|c|c|c|c|c|}
\hline Нуро & Relationship & Original Sample (O) & Mean.Boot & $2.5 \%$ & $97.5 \%$ \\
\hline HP1 & $\begin{array}{l}\text { Applied researches -> } \\
\text { Management development of } \\
\text { employees }\end{array}$ & 0.614 & 0.616 & 0.507 & 0.714 \\
\hline HP2 & $\begin{array}{l}\text { Applied researches -> } \\
\text { Organizational development }\end{array}$ & 0.381 & 0.385 & 0.264 & 0.476 \\
\hline HP3 & $\begin{array}{l}\text { Continuing education -> } \\
\text { Management development of } \\
\text { employees }\end{array}$ & 0.029 & 0.028 & -0.103 & 0.141 \\
\hline HP4 & $\begin{array}{l}\text { Continuing education -> } \\
\text { Organizational development }\end{array}$ & 0.167 & 0.172 & 0.048 & 0.288 \\
\hline HP5 & $\begin{array}{l}\text { Technical consultations -> } \\
\text { Management development of } \\
\text { employees }\end{array}$ & 0.070 & 0.068 & -0.040 & 0.191 \\
\hline HP6 & $\begin{array}{l}\text { Technical consultations -> } \\
\text { Organizational development }\end{array}$ & 0.030 & 0.025 & -0.100 & 0.154 \\
\hline HP7 & $\begin{array}{l}\text { Training -> Management } \\
\text { development of employees }\end{array}$ & 0.184 & 0.185 & 0.069 & 0.276 \\
\hline HP8 & $\begin{array}{l}\text { Training -> Organizational } \\
\text { development }\end{array}$ & 0.221 & 0.219 & 0.114 & 0.319 \\
\hline
\end{tabular}

Table 10 shows that the lower bound and upper bound are positive for the bootstrap value for all favorable hypotheses which are not equal to zero, and thus five research hypotheses are accepted, indicating that there is a positive role for Jouf University in the service and development of the local community. 
Table 11. ANOVA results for the role of Jouf University variable related to demographic variables

\begin{tabular}{llll}
\hline Hypo & Variables & F value & Sig \\
\hline \multirow{4}{*}{ HP9 } & Gender & 5.129 & 0.024 \\
& Age & 12.154 & 0.000 \\
& Education, & 2.917 & 0.034 \\
& Experience & 5.487 & 0.000 \\
& profession & .902 & 0.440 \\
\hline
\end{tabular}

Significant at $\mathrm{P}^{* *}=<0.01, \mathrm{p}^{*<0}<05$

Source: prepared by researchers using SPSS 23 output

Table 11 shows the output of the ANOVA analysis and examines whether there is a statistically significant difference between our group's means of the role of the Jouf University variable. We can see that the significance value of gender groups is 0.024 , which is below 0.05 . Therefore, there is a statistically significant difference in the mean of the role of Jouf University variable between males and females. The same applies to all variables of age, education, and experience. Their significance value is respectively $0.000,0.034$, and 0.000 , which is also below 0.05 . That means there is a statistically significant difference in the mean of the role of Jouf University variable between age groups, between educational levels, and between years of experience. On the other hand, the significance value related to the profession variable is 0.440 , which is greater than 0.05 . So we can say that there is no statistically significant difference in the mean of the role of Jouf University variable between professional groups.

Hypotheses HP9, HP10, HP11 have been tested using the SPSS (23) program as follows:

Table 12. ANOVA results for the management development of employees variable related to demographic variables

\begin{tabular}{llcc}
\hline Hypo & Variables & F value & Sig \\
\hline \multirow{3}{*}{ HP10 } & Gender & 3.798 & 0.052 \\
& Age & 13.902 & 0.000 \\
& Education, & 3.823 & 0.010 \\
& Experience & 7.741 & 0.000 \\
& profession & .727 & 0.536 \\
\hline
\end{tabular}

Significant at $\mathrm{P}^{* *}=<0.01, \mathrm{p}^{*<0.05}$

The output of the ANOVA analysis and whether there is a statistically significant difference between our group's means of management development of employees variable is shown in Table 12. The significance value of gender groups is 0.052 , which is greater than 0.05 , and below 0.10 . Therefore, there is a statistically significant difference at $10 \%$ in the mean of management development of employees variable between males and females, and the variables of age, education, and experience. Their significance value is respectively $0.000,0.010$, and 0.000 , which is also below 0.05 . That means there is a statistically significant difference in the mean of management development of employees variable between age groups, between educational levels, and between years of experience. On the other hand, the significance value related to the profession variable is 0.536 , which is greater than 0.05 . So we can say that there is no statistically significant difference in the mean of management development of employees variable between professional groups.

Table 13. ANOVA results for the organizational development variable related to demographic variables

\begin{tabular}{llcc}
\hline Hypo & Variables & F value & Sig \\
\hline \multirow{4}{*}{ HP11 } & Gender & 1.313 & 0.253 \\
& Age & 12.758 & 0.000 \\
& Education, & 7.047 & 0.000 \\
& Experience & 20.511 & 0.000 \\
& Profession & 0.176 & 0.912 \\
\hline
\end{tabular}

Significant at $\mathrm{P}^{* *}=<0.01, \mathrm{p}^{*<0.05}$ 
Table 13 shows the output of the ANOVA analysis and whether there is a statistically significant difference between our group's means of the organizational development variable. All the significance values of age, education, and experience groups are equal to 0.000 , which is below 0.05 . Therefore, there is a statistically significant difference in the mean of the organizational development variable between age groups, educational levels, and between years of experience. On the other hand, the significance values related to the gender and profession variables are respectively 0.243 and 0.912 , which is greater than 0.05 ; this means there is no statistically significant difference in the mean of the organizational development variable between male and females and between profession groups.

\section{Discussion}

The findings show that hypothesis HP1 is supported: researches have a positive impact on the management development of employees by the 1\% (2.58) level significance - applied researches are focused on analyzing the challenges facing individuals within the work environment of business organizations in the Al-Jouf area; they intend to solve the issues present. HP2 is supported: researches have a positive impact on organizational development by the $1 \%$ (2.58) level of significance - this is because researchers are focused on the study of problems from the reality of the work of business organizations in the Al-Jouf region. It is also carried out in collaboration between faculty members from the university and individuals from business organizations in the Al-Jouf region; thus, it contributes to the organizational development of the enterprises.

HP4 is supported: continuing education has a positive impact on organizational development by the $1 \%$ (2.58) level significance - the explanation for this is that the continuing education programs offered by Jouf University for community service have been chosen based on the needs of the labor market, aimed at the organizational development of business organizations in the Al-Jouf area. HP7 is supported: training has a positive impact on the management development of employees by the 1\% (2.58) level significance - this is due to the study of the training needs of employees in the Al-Jouf region, the description of them specifically, and the design of training programs aimed at meeting these needs, contributing to the organizational development of employees in the Al-Jouf region. HP8 is supported: training has a positive impact on organizational development by the $1 \%$ (2.58) level of significance-this is due to the study of the training needs of employees in the Al-Jouf region, the description of them specifically, and the design of training programs meeting these needs, contributing to the organizational development of employees in the Al-Jouf region.

The findings show that hypothesis HP3 is unsupported: there is no effect of continuing education on the management development of employees - this is due to a lack of interest on the part of individuals in the Al-Jouf area in the continuing education programs provided by Jouf University to support the community, and the participation in such programs was very low. HP5 is unsupported: there is no effect of technical consultations on the management development of employees - this is due to the lack of knowledge among individuals in the Al-Jouf area of the value of technical advice given by Jouf University to support the community, and the number of business organizations in the region is very low compared to the rest of the kingdom's regions.

HP6 is unsupported: there is no effect of technical consultations on organizational development- - this is due to the lack of interest of business organizations in the Al-Jouf area, in providing professional advice to the community to Jouf University, and the majority of business organizations in the region are very small projects and do not care about the consultancy.

\section{Conclusion}

In line with the procedures implemented in this study, the findings are systematized to check validity and reliability. Structural hypothesis and hypothesis testing using SmartPLS 3.3.2, PLS-MGA was done to analyze the measurement model and structural model, to maintain coherence in the progress of arguments and the demonstration of findings. SEM used in this research exposed that there is a positive role of Jouf University in serving and developing society for Vision 2030.

\section{Recommendations}

In pursuance of the findings of the applied study, the following recommendations can be proposed:

1. Try to increase awareness in the internal and external community regarding the role of the university, in serving the community and raising awareness of the importance of these programs and their role in the development and advancement of society

2. Work on setting up those committees and agencies that prepare, organize, and manage the university's community service 
3. Guide university research to support the communities, hold conferences to address community issues, and encourage community leaders to take part in the work and publish such research

4. Directing and encouraging the preparation of master's degree research towards the practical side of the reality of business sectors

5. Working on the marketing of community-based university services in the field of advisory services and research, setting up special centers for that purpose, and inviting businessmen and chambers of commerce and industry to introduce the services they offer.

\section{References}

Azad, B., \& Faraj, S. (2008). Making e-government systems workable: Exploring the evolution of frames. Journal of Strategic Information Systems, 17, 75-98. https://doi.org/10.1016/j.jsis.2007.12.001

Chang, S., \& Hsieh, J. (2011). The dynamics of intellectual capital in organizational development. African Journal of Business Management, 5(6), 2345-2355.

Levkoe, C. Z. (2020). Community service-learning in graduate planning education. Journal of Planning Education and Research, 40(1), 92-103. https://doi.org/10.1177/0739456X18754318

Chin, W. W. (1998). Commentary: Issues and opinion on structural equation modeling.

Clinton \& Thomas. (2011). Business students' experience of community service learning. Asia-Pacific Journal of Cooperative Education, 12(1), 51-66.

Cochran. (2000). Policies for strengthening local government in developing countries. The World Bank.

Cohen, S. (1988). Perceived stress in a probability sample of the United States.

Communications and Information Technology Commission, Communications and Information Technology Sector Performance Indicators until the second quarter of 2020.

Croutsche, J. J. (2002). Étude des relations de causalité: Utilisation des modèles d'équations structurelles (approche méthodologique). La Revue des Sciences de Gestion: Direction et Gestion, (198), 81 . https://doi.org/10.1051/larsg:2002037

Dijkstra, T. K., \& Henseler, J. (2015). Kleve: Composite modeling. Guilford Press.

Fornell, C., \& Larcker, D. F. (1981). Evaluating structural equation models with unobservable variables and measurement error. Journal of Marketing Research, 18(1), 39-50. https://doi.org/10.2307/3151312

Grassl, W. (2010). Aquinas on management and its development. Journal of Management Development, 29(7), 706-715. https://doi.org/10.1108/02621711011059149

Hair, J. F., Jr., Black, W., Babin, B., \& Anderson, R. (2010). Multivariate data analysis: A global perspective. Pearson Education.

Hair, J. F., Jr., Hult, G. T. M., Ringle, C. M., \& Sarstedt, M. A. (2017). Primer on partial least squares structural equation modeling (PLS-SEM) (3rd ed.). Sage Publication. https://doi.org/10.15358/9783800653614

Hesham K., Alfares, et al,. (2013). Community service in Saudi Arabian universities: A Comparative Study. Journal of Community Engagement and Higher Education, 5(2), 56-64.

Jabri, M., \& Pounder, J. S. (2001). The management of change: a narrative perspective on management development. Journal of Management Development, 20(8), 682-691. https://doi.org/10.1108/02621710110401400

Otenyo, E. E., \& Lind, N. S. (2006), “Part II: Administrative Development and Development Administration”, Research in Public Policy Analysis and Management, Volume 15), Emerald Group Publishing Limited, 221-230. https://doi.org/10.1016/S0732-1317(06)15050-2

Reitsma, S. G. (2001). Management development in Unilever. Journal of Management Development, 20(2), 131-144. https://doi.org/10.1108/02621710110382150

Tenenhaus, M., Amato, S., \& Esposito Vinzi, V. (2004). A global goodness-of-fit index for PLS structural equation modelling. In Proceedings of the XLII SIS Scientific Meeting (pp. 739-742).

van der Sluis-den, D. L., \& Hoeksema, L. H. (2001). The palette of management development. Journal of Management Development, 20(2), 168-179. https://doi.org/10.1108/02621710110382187 
Wetzels, M., Odekerken-Schröder, G., \& Van Oppen, C. (2009). Using PLS path modeling for assessing hierarchical construct models: Guidelines and empirical illustration. MIS Quarterly, 177-195. https://doi.org/10.2307/20650284

Wondwosen, T. (2019). Re-engaging with community service in universities. https://www.researchgate.net/publication/332869492.

\section{Note}

Note 1. https://mps.ju.edu.sa/JUSocietyServices/juPublic/generalStatistics.xhtml 10/07/2020

\section{Copyrights}

Copyright for this article is retained by the author(s), with first publication rights granted to the journal.

This is an open-access article distributed under the terms and conditions of the Creative Commons Attribution license (http://creativecommons.org/licenses/by/4.0/). 